American University Washington College of Law

Digital Commons @ American University Washington College of

Law

Articles in Law Reviews \& Other Academic Journals

Scholarship \& Research

2019

Conduct Yourselves Accordingly: Amending Bar Character and Fitness Questions to Promote Lawyer Well-Being

David Jaffe

Janet Stearns

Follow this and additional works at: https://digitalcommons.wcl.american.edu/facsch_lawrev

Part of the Law Commons 


\section{Conduct Yourselves Accordingly: Amending Bar Character and Fitness Questions To Promote Lawyer Well-Being ${ }^{1}$}

Vol. 26 No. 2

By David Jaffe and Janet Stearns ${ }^{2}$

David Jaffe is Associate Dean of Student Affairs at American University Washington College of Law, and a member of the Advisory Committee of the ABA Commission on Lawyer Assistance Programs and the National Task Force on Lawyer Well-Being. Janet Stearns is Dean of Students at the University of Miami School of Law, and a member of the ABA Commission on Lawyer Assistance Programs.

\section{The Character and Fitness Screening Process: Solutions and Problems}

Admission to the practice of law involves an evaluation of substantive knowledge, tested through the administration of the bar examination, and a separate evaluation of character and fitness. The character and fitness process is intended to identify issues that could affect the responsible and competent practice of law. So, for example, bar examiners will ask about an applicant's history relating to honor code and academic integrity, criminal history, civil litigation history, and financial dealings, as each piece of information could bear a relationship to the applicant's ability to practice law in a competent manner.

Deans of Students work daily with law students and counsel them on the professionalism required in law school, as well as the candor required to complete the character and fitness application process. Our role is also to work hand-in-hand with bar regulators to educate the next generation of lawyers and transition them into the legal profession. We have counseled hundreds of law students who have struggled with mental health and substance use issues during law school. Some of these problems are first experienced in law school in the face of academic, financial, and career pressures. In other instances, our law schools have admitted students who have a history of mental health or substance use, but who have overcome these challenges to complete the rigors of law school and prepare themselves for the demands of the bar examination and the profession.

It is deeply troubling that our law students and our profession struggle with substance use and mental health issues. The Survey of Law Student Well-Being ${ }^{3}$ updated and confirmed the belief among those in the legal profession, particularly at law schools, that law students are continuing to struggle with substance use disorder and other mental health disorders. The survey of 3,300 law school students across fifteen law schools found that more than one in six screened positive for depression and nearly one in four screened for anxiety. 
Forty-two percent of the survey respondents indicated they felt they needed mental health intervention, but $45 \%$ would not seek help, believing it would threaten their ability to be admitted to the bar. At the same time, $63 \%$ of respondents reported that the potential threat to bar admissions was a factor discouraging them from seeking services for substance use. Almost half of the respondents reported their belief that they had a better chance of getting admitted to the bar if a substance use problem were hidden, and $44 \%$ of respondents reported their belief that they had a better chance of getting admitted to the bar if a mental health problem were hidden.

These numbers are overwhelming evidence of student concerns about the risks to bar admission if they disclose substance use or mental health issues after seeking treatment and support. The source of these concerns must be addressed by clarifying what should, and what should not, need to be disclosed as part of the character and fitness evaluation process.

Provided that bar applicants can perform the essential elements and duties of a lawyer with competence and diligence, overbroad or outdated character and fitness questions should not stand in the way of their admission. The character and fitness process is appropriate when it identifies conduct that could adversely affect the applicant's ability to practice law. Examples of conduct might include an arrest for driving under the influence of alcohol; attendance problems in class, clinics or externships; mismanaging personal funds; or the inability to meet deadlines. All of these are relevant and fair issues for evaluation.

The character and fitness process, however, is not serving its purpose when the focus is on a particular mental health diagnosis or condition. The current perception among law students is that an applicant who receives treatment for a mental health issue and then discloses this treatment on the bar application will create a delay or denial of admission. As a result, the law student who perceives needing help will not seek it when it is most needed. Further, a history of mental health or substance use issues has not been shown to reflect in a lawyer's ability to practice law. ${ }^{4}$ Consequently, the character and fitness process should allow for an individual with mental health or substance use issues prior to law school, who spends three successful years in school without incident, to seek treatment or otherwise be admitted without being subject to questions of condition or diagnosis. Again, the focus should remain on recent conduct and behavior, rather than an overinclusive, inappropriate (and illegal) application of a stigma.

Further, a focus on certain health conditions, without asking about all health conditions, is underinclusive. If bar examiners wish to know about any medical situation that could potentially affect one's ability to practice law, the questions should focus on a wide range of medical issues (brain injury, Tourette's Syndrome, obesity, cancer, concussions, epilepsy, diabetes, to name a few.). But questions that focus solely on mental health continue to stigmatize future members of the profession, and this stigma is preventing exactly the type of treatment and appropriate helpseeking behavior that we should be encouraging. 
This paper summarizes the relevant national legal history over the past five years and describes significant state law developments during this time period. We also articulate a national agenda for reform, and where the American Bar Association, the National Conference of Bar Examiners, and State Bars can each play a significant role.

\section{Recent History in the Debate on Substance Use and Mental Health Questions in the Character and Fitness Process}

\section{A. Louisiana Consent Decree}

In 2014, the U.S. Department of Justice ("DOJ") announced strong opposition to broad-based mental health questions on bar applications, thus sending a significant message across the nation. DOJ launched a substantial investigation of the Louisiana attorney licensure system in 2011 when applicants with mental health disabilities alleged that they were subject to "additional inquiries and/or conditions on admission on account of mental health disability." 5 Wile not the first legal attack to the bar admission process under the Americans with Disabilities Act (ADA), this investigation directly challenged the reliance upon improper questions by the Louisiana Supreme Court Committee on Bar Admissions and the process by which these questions were evaluated. ${ }^{6}$ Specifically, candidates for admission had to respond to questions developed by the National Conference of Bar Examiners ("NCBE") as part of its character report process. The questions at issue were:

" 25 . Within the past five years, have you been diagnosed with or have you been treated for bipolar disorder, schizophrenia, paranoia, or any other psychotic disorder?

26A. Do you currently have any condition or impairment (including but not limited to, substance abuse, alcohol abuse, or a mental, emotional, or nervous disorder or condition) which in any way affects, or if left untreated, could affect your ability to practice law in a competent and professional manner?

26B. If your answer to $26 \mathrm{~A}$ is yes, are the limitations caused by your mental health condition....reduced or ameliorated because you receiving ongoing treatment (with or without medication) or because you participate in a mentoring program?

27. Within the past five years have you ever raised the issue of consumption of drugs or alcohol or the issue of a mental, emotional, nervous, or behavioral disorder or condition as a defense, mitigation, or explanation for your actions in the course of any administrative or judicial proceeding or investigation, any inquiry or other proceeding; or any proposed termination by an educational institution, employer, government agency, professional organization, or licensing authority?" 
The DOJ investigation resulted in a consent decree on August 15, 2014 with the Louisiana Supreme Court that prohibited the court from asking bar applicants questions about diagnosis and treatment "which did not effectively predict future misconduct as an attorney." The decree mandated that the Court: "Refrain from inquiring into mental health diagnosis or treatment, unless (1) an applicant voluntarily discloses this information to explain conduct or behavior that may otherwise warrant denial of admission, ... or (2) the Committee learns from a third-party source that the applicant raised a mental health diagnosis or treatment as an explanation for conduct or behavior that may otherwise warrant denial of admission. Any such inquiry shall be narrowly, reasonably, and individually tailored." 8

The consent decree sent a powerful signal to state supreme courts nationally and established standards for compliance with the ADA. The updated standard was that screening questions should focus on "conduct or behavior", with reference to condition or impairment only when there is an effect on the ability of the applicant to competently and ethically practice law. The announcement of this consent decree delivered a significant signal to bar regulators to re-evaluate the existing approach to character and fitness questions addressing substance use and mental health.

In August 2015, one year after the Louisiana consent decree, the American Bar Association (ABA) Commission on Disability Rights submitted Resolution 102 to the House of Delegates. This resolution, building upon the language of the consent decree, urged further action by licensing entities around the country:

\section{RESOLVED, That the American Bar Association urges state and territorial bar licensing entities to eliminate from applications required for admission to the bar any questions that ask about mental health history, diagnoses, or treatment and instead use questions that focus on conduct or behavior that impairs an applicant's ability to practice law in a competent, ethical, and professional manner. [emphasis added]}

FURTHER RESOLVED, That state and territorial bar licensing entities are not precluded from making reasonable and narrowly-tailored follow-up inquiries concerning an applicant's mental health history if the applicant has engaged in conduct or behavior that may otherwise warrant a denial of admission and a mental health condition either has been raised by the applicant as, or is shown by other information to be, an explanation for such conduct or behavior. ${ }^{9}$

The 2015 Resolution placed on the ABA on the record as to the importance of eliminating questions that focus on diagnosis and replacing them with conduct-focused questions. Although approved and adopted by the ABA, a larger movement was required before states started to take action. 


\section{B. National Task Force Report}

A coalition of national legal associations ${ }^{10}$ came together to form the National Task Force on Lawyer Well-Being, largely in response to the results of the Survey of Law Student Well-Being and a parallel survey on the legal profession. ${ }^{11}$ The latter survey found, inter alia, that attorneys are struggling with substance use disorder during the first ten years in their practice, reversing a belief that these problems arose with greater frequency as attorneys aged. ${ }^{12}$

In 2017, the National Task Force on Lawyer Well-Being released "The Path to Lawyer WellBeing: Practical Recommendations for Positive Change." 13 The report presents a wide array of significant recommendations for stakeholders across the legal profession. A number of these recommendations transcend the scope of this paper. Central to this paper is that the report asked regulators ${ }^{14}$ to adjust the bar admissions process to support law student well-being. The report called upon regulators to:

- Re-evaluate bar application inquiries about mental health history.

- $\quad$ Adopt essential eligibility admission requirements.

- Adopt a rule for conditional admissions to practice law with specific requirements and conditions.

Publish data reflecting the low rate of denied admissions due to mental health disorders and substance use.

A broad coalition of entities ${ }^{15}$ endorsed the structural reform proposed in the National Task Force Report, including a close evaluation of any character and fitness process which asks applicants questions which do not effectively predict future misconduct. Many states have since created their own Task Forces to focus on lawyer well-being. ${ }^{16}$

Following the release of the Report, a coalition of groups - including the ABA Working Group to Advance Lawyer Well-Being, the ABA Commission on Lawyer Assistance Programs, the ABA Standing Committee on Professionalism, and the National Association of Bar Counsel - joined forces at the ABA's Midyear Meeting in 2018 to go one step further.

In February 2018, these groups asked the ABA House of Delegates to adopt Resolution 105, which supported the goal of reducing mental health and substance use disorders and improving the wellbeing of lawyers, judges, and law students. Resolution 105 reads:

RESOLVED, That the American Bar Association supports the goal of reducing mental health and substance use disorders and improving the well-being of lawyers, judges and law students; and 
FURTHER RESOLVED, That the American Bar Association urges all federal, state, local, territorial, and tribal courts, bar associations, lawyer regulatory entities, institutions of legal education, lawyer assistance programs, professional liability carriers, law firms, and other entities employing lawyers to consider the recommendations set out in the report, The Path to Lawyer Well-Being: Practical Recommendations for Positive Change, by the National Task Force on Lawyer Well-Being. [emphasis added] ${ }^{17}$

The strength of this coalition, and the ongoing national press focus on issues relating to lawyer well-being, has brought a renewed campaign to ensure that the character and fitness questions in all U.S. jurisdictions are in compliance with the standards set forth in the Louisiana consent decree.

\section{Conference of Chief Justices Resolutions}

The Conference of Chief Justices (CCJ) was established in 1949 and is composed of the highest judicial officer of each of the 50 United States as well as the District of Columbia, Puerto Rico, and the American territories. The CCJ passes resolutions on various issues of policy affecting the judicial system.

In August 2017, the CCJ voted in favor of a general endorsement of the National Task Force Report with Resolution 6, which states in pertinent part:

WHEREAS, the National Task Force on Lawyer Well-Being issued a report, 'The Path to Lawyer Well-Being: Practical Recommendations for Positive Change,' which contains 44 recommendations, including recommendations for judges, regulators, legal employers, law schools, bar associations, and lawyer professional liability carriers; and

WHEREAS, the Report makes the following recommendations for judges:

-Communicate that well-being is a priority

-Develop policies for impaired judges

-Reduce stigma of mental health and substance use disorders

-Conduct judicial well-being surveys

-Provide well-being programming for judges and staff

-Provide monitoring for impaired lawyers and partner with Lawyer Assistance Programs; and

WHEREAS, the Conference of Chief Justices fully supports the concept of lawyer wellbeing as a critical component of lawyer competence, and reinforces the critical role of the highest court in each jurisdiction in overseeing the legal profession; and 
WHEREAS, the Conference of Chief Justices recognizes that the highest court in each jurisdiction should take an active role in the development of effective mechanisms for the regulation of the legal profession, including convening the relevant stakeholders in each jurisdiction to improve lawyer well-being;

NOW, THEREFORE, BE IT RESOLVED that the Conference of Chief Justices supports the goals of reducing impairment and addictive behavior, and improving the well-being of lawyers, and recommends that each jurisdiction considers the recommendations of the Report of the National Task Force on Lawyer Well-Being. ${ }^{18}$

Following this general endorsement of the National Task Force, a year later Massachusetts Supreme Court Chief Justice Ralph Gants proposed another resolution to specifically address the breadth of the character and fitness questions. ${ }^{19}$ On February 13, 2019, the CCJ adopted the following Resolution as a significant demonstration of support for the goal of ensuring that all the member jurisdictions revise their bar application questions with respect to mental health and substance use issues:

Resolution 5

"In Regard to the Determination of Fitness to Practice Law

WHEREAS, the courts of last resort in the respective states and territories exercise responsibility over the process for the admission of the attorneys to the practice of law; and

WHEREAS, as part of the admissions process, state bar admission authorities evaluate the character and fitness of applicants for admission to practice law; and

WHEREAS, in addition to conduct and behavior-related questions, some states inquire about applicants' mental health diagnoses and treatment unrelated to conduct and behavior; and

WHEREAS, the U.S. Department of Justice has made findings in an Americans with Disabilities Act (ADA) investigation of bar licensure that questions about medical conditions as part of a fitness inquiry inappropriately focus on an applicant's status as a person with a disability, rather than on the applicant's conduct; and

WHEREAS, questions about mental health history, diagnoses, or treatment are unduly intrusive, may tend to screen out individuals with disabilities, may violate the Americans with Disabilities Act, and are likely to deter individuals from seeking mental health counseling and treatment; and 
WHEREAS, applicants with disabilities should be assessed, like all other applicants, solely based on their current fitness to practice law; and

WHEREAS, the Department of Justice also has made findings in an ADA investigation of bar licensure that to comply with the ADA, "attorney licensing entities must base their admissions decisions on an applicant's record of conduct, not the applicant's mental health history," and

WHEREAS, public entities cannot impose or apply eligibility criteria that tend to screen out an individual with a disability from fully and equally enjoying any service, program, or activity, unless such criteria can be shown to be necessary for the provision of the service, program, or activity;

NOW, THEREFORE, BE IT RESOLVED that the Conference of Chief Justices urges its members and state and territorial bar admission authorities to eliminate from applications required for admission to the bar any questions that ask about mental health history, diagnoses, or treatment and instead use questions that focus solely on conduct or behavior that impairs an applicant's current ability to practice law in a competent, ethical, and professional manner;

BE IT FURTHER RESOLVED that reasonable inquiries concerning an applicant's mental health history are only appropriate if the applicant has engaged in conduct or behavior and a mental health condition has been offered or shown to be an explanation for such conduct or behavior." [emphasis added] ${ }^{20}$

With the support of the immediate past President of the Conference of Chief Justices, Vermont Chief Justice Paul Reiber, the adoption of this Resolution provides the strongest endorsement for ongoing reform. The recommendations herein build upon the momentum created by the CCJ Resolution.

\section{Role of the National Conference of Bar Examiners and the Uniform Bar Exam}

The National Conference of Bar Examiners (NCBE), is a not-for-profit corporation founded in 1931 whose mission includes working with other institutions to "develop, maintain, and apply reasonable and uniform standards of education and character for eligibility for admission to the practice of law; and assist bar admission authorities by providing standardized examinations of uniform and high quality for the testing of applicants for admission to the practice of law; . . and provide other services such as character and fitness investigations and research." 21

NCBE does not make rules regarding the admission of candidates, nor does it make a final determination on admission. The NCBE does however host a character and fitness screening application used by 22 jurisdictions for attorneys seeking: 1) first time admission, 2) attorney admission on motion (licensed in another U.S. jurisdiction or territory); 3) foreign- 
educated/foreign-licensed, and 4) admission by transferred Uniform Bar Exam (UBE) score. ${ }^{22}$ Three additional jurisdictions use the character and fitness questions only for admission review of foreign educated attorneys and one jurisdiction only for admission by motion. Thus, 26 jurisdictions are directly affected by the character and fitness screening questions as drafted by the NCBE.

Of the jurisdictions NCBE works with to provide character and fitness services, 20 use the standard language from the NCBE application, five use nonstandard language for some or all of the mental health questions, and three do not use any of the mental health questions (the questions are suppressed and do not appear).

The NCBE questions were revised in 2014 in response to the State of Louisiana consent decree. But given the ongoing attention on these issues, and the fact that these questions are being used in the majority of jurisdictions, we should again take a critical look at whether they represent the appropriate balance of interests. Because the questions are widely used, they are provided here: ${ }^{23}$

\section{Conduct or Behavior}

Within the past five years, have you exhibited any conduct or behavior that could call into question your ability to practice law in a competent, ethical, and professional manner?

\section{Condition or Impairment}

Do you currently have any condition or impairment (including, but not limited to, substance abuse, alcohol abuse, or a mental, emotional, or nervous disorder or condition) that in any way affects your ability to practice law in a competent, ethical, and professional manner?

If Yes, are the limitations caused by your condition or impairment reduced or ameliorated because you receive ongoing treatment or participate in a monitoring or support program?"

While Question 29 is consistent with the framework set forth in the Louisiana Consent Decree, for the reasons set forth above NCBE should delete Question 30.

Until 2018, the NCBE application included a Preamble to the mental health and substance use questions. ${ }^{24}$ The since-removed Preamble stated:

Through this application, the National Conference of Bar Examiners makes inquiry about circumstances that may affect an applicant's ability to meet the professional responsibilities of a lawyer. This information is treated confidentially by the National Conference and will be disclosed only to the jurisdiction(s) to which a report is submitted. The purpose of such inquiries is to allow jurisdictions to determine the current fitness of an applicant to practice law. The mere fact of treatment, monitoring, or participation in a support group is not, in itself, a basis on which admission is denied; boards of bar examiners routinely certify for admission individuals who demonstrate personal responsibility and maturity in dealing with fitness issues. The National Conference encourages applicants who may benefit from assistance to seek it. 
Boards do, on occasion, deny certification to applicants whose ability to function is impaired in a manner relevant to the practice of law at the time that the licensing decision is made, or to applicants who demonstrate a lack of candor by their responses. This is consistent with the public purpose that underlies the licensing responsibilities assigned to bar admission agencies; further, the responsibility for demonstrating qualification to practice law is ordinarily assigned to the applicant in most jurisdictions.

The National Conference does not seek information that is fairly characterized as situational counseling. Examples of situational counseling include stress counseling, domestic counseling, grief counseling, and counseling for eating or sleeping disorders. The National Conference does not seek medical records.

Preambles are helpful to applicants' understanding the goals and intentions of the licensing authority in evaluating their responses. Thus, the removal of the NCBE Preamble may be problematic for all applicants, including applicants with a history of substance use or other mental health conditions. This Preamble provided critically important guidance to applicants as they approached the process of responding to character and fitness questions and perhaps sought guidance on help-seeking behavior during law school.

Inasmuch as the public statement of policy as provided in this Preamble was very helpful to bar applicants and their counselors and advisors, the decision to remove this statement was a step backward.

\section{E. Bazelon's Fifty State Analysis}

The Bazelon Center for Mental Health Law is a non-profit organization that since 1972 has advocated for the civil rights, full inclusion, and equality of adults and children with mental disabilities.

In spring 2019, Bazelon conducted a review of and subsequently published the Bar Exam Character and Fitness Questions for all fifty States and the District of Columbia. ${ }^{25}$ While Bazelon opted not to specify or flag those states for which character and fitness questions appear invasive, contrary to the Louisiana decree, and/or likely to cause an applicant to reconsider applying, by providing every state's questions in one table Bazelon's research demonstrates the following:

- Breadth of Questions: A number of states ask questions that are not limited in time or scope or seek applicant responses that appear overbroad with respect to the period of time sought and are not directed at an applicant's ability to practice law.

- Questions Calling for Diagnosis: A number of states continue to ask questions related to an applicant's diagnosis, rather than to the applicant's conduct or behavior, despite the Louisiana decree and the resolutions adopted by bar and bench entities. 
- Speculative Questions: A number of states ask questions that call for speculation on the part of the applicant (i.e., "... that could affect your ability to practice law”). Said questions not only seek information potentially unanswerable by an applicant but are no more appropriate than asking a bar applicant if a physical (non-hidden) condition could affect his or her ability to practice law.

- Questions Requiring Excessive Medical Disclosure: A number of states ask questions that can result in requiring disclosure of significant personal health care information, medications, and diagnostic notes, which are not only invasive but may come at a burdensome cost to the applicant.

The Bazelon survey offers readers an important snapshot of the relevant questions asked in all United States jurisdictions and allows for an ease of comparison of the questions addressing mental health and/or substance use disorders.

\section{States Adopting Significant Recent Changes}

While many states have not changed their practices after the 2014 Louisiana Consent Decree and subsequent bench and bar urgings, several states have recognized the need for change. Below is information from those states:

California - On July 30, 2019, Governor Gavin Newsom signed Senate Bill 544 into law. This bill amended the California Business and Professions Code Section 6060, and generally prohibits the State Bar of California, or members of its Examining Committee, from reviewing or considering a person's medical records relating to mental health, except as specified, during the moral character determination process for attorney licensure. The limited exceptions to this prohibition are if the records are being used to show good moral character or to demonstrate a mitigating factor to a specific act of misconduct. This statutory change will go into effect January $1,2020$.

Connecticut - In January 2018, the Connecticut Bar Examining Committee voted to remove mental health questions from the character and fitness analysis entirely, as reported by the Connecticut Bar Tribune. ${ }^{26}$ The website for the Connecticut Bar Examining Committee has a "protocol" for applicants with health diagnosis or drug or alcohol dependence, and clarifies that they are looking to instances where conduct is involved and that these issues were disclosed to explain the conduct. ${ }^{27}$

Florida - In October 2018, the Florida Board of Bar Examiners ("FBBE") announced significant changes in its approach to substance use and mental health questions. This followed a year of substantial attention to mental health issues through the leadership of the 2017-2018 Bar President 
Michael Higer and past Chair of the Florida Board of Bar Examiners Scott Baena. Significantly, Florida has implemented four important reforms:

1) Reform of the mental health questions on the character and fitness portion. ${ }^{28}$

2) The addition of a broad frequently asked questions section ("FAQ") that addresses and states the FBBE's position on substance use and mental health disclosures.

(https://www.floridabarexam.org/web/website.nsf/faq.xsp);

3) Substantial training of hearing panels on appropriate and inappropriate questions so that bar hearings are constructive rather than traumatizing to applicants. ${ }^{29}$

4) An agreement to assume expenses for any additional testing or evaluation required of bar applicants. ${ }^{30}$

Michigan- The Michigan State Bar Board of Commissioners wrote in March 2019 to the Michigan Supreme Court requesting reform of the character and fitness process. Michigan Lawyers \& Judges Assistance Program (LJAP) Director Tish Vincent, on behalf of the Bar, has requested reform of the character and fitness questions in accordance with the Louisiana consent decree. Further, the Michigan LJAP has requested that a psychologist or experienced mental health professional be available at all bar hearings involving applicants with substance use or mental health history to ensure that the hearing reflects appropriate sensitivity to the applicants and ADA issues. $^{31}$

New York - The current President of the New York Bar Association, Henry Greenberg, announced in June 2019 that he was launching a blue-ribbon committee to determine if the state should remove questions about mental health disorders from applications for the bar. On August 13, 2019, the Working Group on Attorney Mental Health of the New York State Bar Association issued its report The Impact, Legality, Use and Utility of Mental Disability Questions on the New York State Bar Application. This report calls for the complete removal of Question 34 on the New York Bar Application given its negative impact upon law students. ${ }^{32}$ The report also raises "serious doubt" as to the legality of asking Question 34 in light of the ADA. ${ }^{33}$ The report concludes: "It is the conclusion of the Working Group on Attorney Mental Health that mental health inquiries should be eliminated from the application for admission to the Bar of New York State." 34 The New York State Bar Association voted November 2 to adopt the recommendations of the report. ${ }^{35}$ As of the publication of this article, a final determination on whether the question will be eliminated is pending before the New York Administrative Board of the Courts. ${ }^{36}$

Virginia - Effective January 1, 2019, the Virginia bar no longer asks applicants to disclose the applicant's mental health conditions and treatment. In this instance the change resulted when University of Richmond School of Law student organizations requested, and a Virginia Supreme Court committee recommended, that the Virginia Board of Bar Examiners make the change. The law students and the court committee argued that such questions discourage law students from seeking help for fear they will be denied admission to the bar. 
The Virginia question asked if applicants had any "condition or impairment (including, but not limited to, a substance or alcohol use disorder, or a mental, emotional, or nervous disorder or condition)" that might impact their ability to be a lawyer. The updated question asks "[W]ithin the past five (5) years, have you exhibited any conduct or behavior that could call into question your ability to perform any of the obligations and responsibilities of a practicing lawyer in a competent, ethical and professional manner?"

The students' letter to the Virginia Board of Bar Examiners referenced ABA Resolution 105, infra, which urges stakeholders to consider the recommendations in the August 2017 report by the National Task Force on Lawyer Well-Being, including the recommendation to "re-evaluate bar application inquiries about mental health history." 37

\section{An Agenda for Reform}

Changes in law, policy, and regulations can proceed slowly, and often involve a number of relevant organizations, stakeholders, and decision-makers. However, in light of the importance of the character and fitness evaluation process to the health and well-being of law students nationally, and the aforementioned support and recommendations of stakeholders, the following actions need to be taken:

First, State Supreme Courts and Bar Examiners must:

- Remove any character and fitness questions that address mental health and other substance use issues that do not specifically address actual and recent conduct. NCBE Question \#29 is an appropriate framing of the character and fitness question. It reads:

Within the past five (5) years, have you exhibited any conduct or behavior that could call into question your ability to perform any of the obligations and responsibilities of a practicing lawyer in a competent, ethical and professional manner?

States that do not eliminate questions based upon condition or impairment within a reasonable time frame should justify this inaction and provide the rationale or evidence for inaction.

- Ensure that online and print materials about the character and fitness review process include an appropriate preamble or FAQ that clarifies what must and what need not be disclosed, so as not to discourage appropriate help-seeking behaviors by applicants. The preamble or FAQ must clarify with examples the types of conduct that would be disclosable, such as criminal incidents, financial mismanagement, or chronic absenteeism. But it is also essential that the FAQ clarify that there is no requirement of disclosure of medical conditions, treatment, or past history of substance use or mental health.

- Use educational opportunities with law students to clarify the message that appropriate counseling for mental health conditions is encouraged and appropriate. 
- Provide training to bar members involved in the character and fitness process and include, where possible, trained mental health professionals in such hearings so that medical information can be appropriately evaluated and hearings are handled with sensitivity.

Second, the NCBE must:

- Lead the way by ensuring that its character and fitness questions are focused on actual and recent conduct. To that end, NCBE should eliminate Question \# 30, as stated herein.

- Further, NCBE should reinstate a preamble or develop an appropriate list of FAQs, to ensure that its policy and approach to character and fitness does not discourage critical help-seeking behaviors by applicants while they are in law school. More specific examples of the types of information as to conduct that should be disclosed would be an important addition to the preamble. Inasmuch as nearly half of U.S. jurisdictions are utilizing the NCBE character and fitness questions, the effect of NCBE reforms in this area would be substantial.

Third, the ABA should:

- Dedicate appropriate resources to monitor and report on jurisdictional changes that come about as a result of its previously adopted Resolutions, and should use the platform of CLE education, publications, and other media to continue to bring attention to this critical issue.

- Through the Section on Legal Education, ensure that all accredited law school are dedicating appropriate services to law student well-being and basic education to all law students about essential self-help resources.

Working hand in hand, law school professionals together with bar regulators can make a significant contribution towards the well-being of the next generation by ensuring that the character and fitness process is serving its essential and critical function. Probing into mental health and substance use treatment history or diagnosis is stigmatizing and in the process discouraging exactly the type of self-care that competent professionals should be encouraged to seek. A targeted character and fitness process can serve its essential and critical function and still promote lawyer well-being. Let us work together to do better.

\footnotetext{
${ }^{1}$ The views expressed herein represent the opinions of the authors. They have not been approved by the House of Delegates or the Board of Governors of the American Bar Association and, accordingly, should not be construed as representing the position of the Association or any of its entities. Nothing contained herein is to be considered as the rendering of legal advice for specific cases, and readers are responsible for obtaining such advice from their own legal counsel.
} 
${ }^{2}$ The authors appreciate the generous comments and contributions of Bree Buchanan, Edwin O'Dell, Terry Harrell, Doug Ende, Jan Jacobowitz, Steven Moawad, Jarrod Reich, Susan Stefan, Susan Wawrose, and Marilyn Wellington. All errors, however, are the responsibility of the authors.

${ }^{3}$ Published as Suffering in Silence: The Survey of Law Student Well-Being and the Reluctance of Law Students to Seek Help for Substance Use and Mental Health Concerns, vol. 66, J. LEGAL EdUCATION, no. 1 (2016).

${ }^{4}$ See, e.g., Alyssa Dragnich, Have You Ever...? How State Bar Association Inquiries into Mental Health Violate the Americans with Disabilities Act, 80 BROOK. L. REV. 677, 718 (2015) (suggesting that a prior diagnosis or mental health issues has "no predictive value of an applicant's ability to practice law in the future").

${ }^{5}$ SETTLEMENT AGREEMENT BETWEEN THE UNITED STATES OF AMERICA AND THE LOUISIANA Supreme COURT UNDER THE AMERICANS WITH DisABILITIES ACT (Aug. 14, 2014), available at https://www.ada.gov/louisianasupreme-court_sa.htm.

${ }^{6}$ See generally Jon Bauer, The Character of the Questions and the Fitness of the Process: Mental Health, Bar Admissions and the Americans with Disabilities Act, 49 UCLA L. ReV. 93 (2001) \& Alyssa Dragnich, Have You Ever...? How State Bar Association Inquiries into Mental Health Law Violate the Americans with Disabilities Act, 80 BROOK. L. REV., Issue 3 (2015).

${ }^{7}$ SetTlement AgReEMENT BetweEn the United States of America AND the Louisiana Supreme Court UNDER THE AMERICANS WITH DisABILITIES ACT (Aug. 14, 2014), available at https://www.ada.gov/louisianasupreme-court sa.htm.

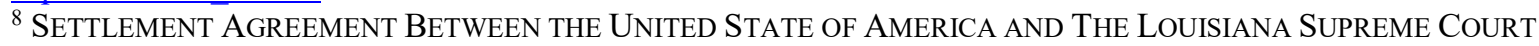
UNDER THE AMERICANS WITH DISABILITIES ACT (Aug. 15, 2014), available at https://www.ada.gov/louisianasupreme-court sa.htm.

${ }_{9}^{9}$ ABA Strengthens Policies on Mental Health Forms for Bar Admissions, Law School Financing, (Aug. 4, 2015) https://www.americanbar.org/news/abanews/aba-news-archives/2015/08/aba strengthens_poli/.

${ }^{10}$ Primary stakeholders were the Commission on Lawyer Assistance Programs, the National Organization of Bar Counsel, and the Association of Professional Responsibility Lawyers. See The PATH to LAWYER Well-BeIng: PRACTICAL RECOMMENDATIONS FOR POSITIVE CHANGE, https://lawyerwellbeing.net/wpcontent/uploads/2017/11/Lawyer-Wellbeing-Report.pdf [hereinafter THE PATH TO LAWYER WELL-BEING] (last visited Nov. 26, 2019).

${ }^{11}$ Patrick R. Krill, Ryan Johnson, Linda Albert, The Prevalence of Substance Use and Other Mental Health Concerns Among American Attorneys, vol. 10, JAMA (2016).

${ }^{12} I d$. at 6.

${ }^{13}$ See The Path to Lawyer Well-Being, supra note 10.

${ }^{14}$ The National Task Force on Lawyer Well-Being report defines regulators broadly as "all stakeholders who assist the highest court in each state in regulating the practice of law." See THE PATH TO LAWYER WELL-BEING, supra note 10 , at 25 .

${ }^{15}$ Endorsing organizations include: ABA Law Practice Division, ABA Center for Professional Responsibility, Association of Professional Responsibility Lawyers, ABA Commission on Lawyer Assistance Programs, Conference of Chief Justices, National Conference of Bar Examiners, and the National Organization of Bar Counsel.

${ }^{16}$ See Monica M. Marquez \& Jonathan White, Call to Action: The Colorado Supreme Court's Task Force on Lawyer Well-Being, 96 DENV. U. L. REV. 247 (2019).

${ }^{17}$ See ABA Commission on Lawyer Assistance Programs, Policy, https://www.americanbar.org/groups/lawyer_assistance/policy/ (last visited Nov. 26, 2019).

${ }^{18}$ See https://ccj.ncsc.org/Policy-Resolutions.aspx ("Lawyer Conduct")

${ }^{19}$ Substantial support for this resolution included Massachusetts Board of Bar Examiners Executive Director Marilyn Wellington.

${ }^{20}$ See Conference of Chief Justices, Policy Resolutions, BAr Admission, https://ccj.ncsc.org/Policy-

Resolutions.aspx (last visited Nov. 26, 2019).

${ }^{21}$ NATIONAL CONFERENCE OF BAR EXAMINERS, ABOUt Us, http://www.ncbex.org/about/ (last visited Nov. 26, 2019).

22 See National Conference of Bar Examiners, Character and Fitness Examinations, http://www.ncbex.org/character-and-fitness [hereinafter CHARACTER AND FITNESS]. See also Bazelon's Fifty State Analysis, infra note 26.

${ }^{23}$ See ChaRACTER AND Fitness, supra note 22; See Memo of President Erica Moeser to Bar Admission Administrators dated February 4, 2014 (on file with authors).

${ }^{24}$ Presentation of Matt Samuelson, National Conference of Bar Examiners, at the COLAP National Conference, Sept. 27, 2018. 
${ }^{25}$ Bar Exam Resources for Law Students and Graduates, BAZELON CENTER, http://www.bazelon.org/ourwork/education/bar-exam-resources-for-law-students-and-graduates/ (last visited Nov. 26, 2019).

${ }^{26}$ Long Overdue Step Taking To Remove Mental Health Stigma in the Law, LAW.COM, (Apr. 12, 2019, 11:41 AM), https://www.law.com/ctlawtribune/2019/04/12/long-overdue-step-taken-to-remove-mental-health-stigma-inlaw/?slreturn=20191026164131.

${ }^{27}$ Regulations of the Connecticut Bar Examining Committee, STATE BAR OF CONNECTICUT JUdicIAL BRANCH, https://www.jud.ct.gov/cbec/regs.htm\#VI (last visited Nov. 26, 2019).

${ }^{28}$ Florida Board of Bar Examiners Questions 25 and 26 now read:

"Substance Use and Mental Health

The Board of Bar Examiners, as part of its responsibility to protect the public, must assess whether an applicant manifests any mental health or substance use issue that impaired or could impair the applicant's ability to meet the essential eligibility requirements for the practice of law.

The Board supports applicants seeking mental health or substance use treatment, and views effective treatment by a licensed professional as enhancing the applicant's ability to meet the essential eligibility requirements to practice law.

Seeking counseling to assist with stress or anxiety will not adversely affect the outcome of a Florida Bar application. The Board does not request that applicants disclose such counseling.

Within the past 5 years, have you been treated for, or experienced a recurrence of, schizophrenia or any other psychotic disorder, bipolar disorder, or major depressive disorder, that has impaired or could impair your ability to practice law.

Within the past 5 years, have you been treated for, or had a recurrence of, a substance-related disorder that has impaired or could impair your ability to practice law?"

${ }^{29}$ Interview with Scott Baena, Chair, Florida Board of Bar Examiners.

${ }^{30}$ See Florida BOARD OF BAR EXAMINERS, BAR EXAMINERS MODIFy DisORdER EVALUATION ReQuiremENTS (2019), https://www.floridabarexam.org/web/website.nsf/52286AE9AD5D845185257C07005C3FE1/6EEF117694DE6506 852583CB00742D8F

${ }^{31}$ Notes on file with authors.

32 The PATH TO LAWYER Well-BeING, supra note 10, at 33.

${ }^{33}$ Question 34 is comprised of three subparts. First, the applicant is asked, "Do you have any condition or impairment ... which in any way impairs or limits your ability to practice law?" Second, the applicant is instructed, "If your answer is Yes, describe the nature of the condition or impairment." Third, the applicant who answered the first subpart affirmatively is asked if the limitations caused by the condition or impairment are "reduced or ameliorated because you receive ongoing treatment or because you participate in a monitoring or support program." See The PATH to LAWYer Well-BeING, supra note 10, at 22.

${ }^{34}$ Susan DeSantis, Momentum Builds for Allowing NY Bar Applicants to Keep Mental Health History Secret, N.Y. LAW JOURNAL (2019), https://www.law.com/newyorklawjournal/2019/06/10/momentum-builds-for-allowing-nybar-applicants-to-keep-mental-health-history-secret/.

${ }^{35}$ N.Y. Bar Association Calls for Mental Health Question Ban, Bloomberg News, (Nov. 2, 2019), https://news.bloomberglaw.com/us-law-week/n-y-bar-association-calls-for-mental-health-question-ban. ${ }^{36} I d$.

${ }^{37}$ See Justin Mattingly, Virginia Panel Scraps Mental Health Question After Law Student Push, RICHMOND TIMESDisPATCH (Feb. 8, 2019), https://www.richmond.com/news/local/education/virginia-panel-scraps-mental-healthquestion-after-law-school-student/article 36ece9b3-078c-5e12-b748-762555b8f081.html. 